\title{
HOPELESSNESS DITINJAU DARI KEPUASAN HIDUP PADA PASIEN KANKER PAYUDARA DI RSUD ARIFIN ACHMAD PROVINSI RIAU
}

\author{
Henni Sinthya ${ }^{1}$, Diny Atrizka ${ }^{2}$, Nurmaizar Nilawati Siregar ${ }^{3}$ \\ ${ }^{I}$ Fakultas Psikologi, Universitas Prima Indonesia, 20111 Medan, Sumatera Utara \\ Email : 'hennisinthya@gmail.com
}

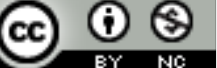

$\mathrm{nc} / 4.0 /$ )

\begin{abstract}
This study aims to examine the relationship between life satisfaction with hopelessness. The hypothesis of this research is that there is neagtive relationship between life satisfaction and hopelessness among breast cancer patients. This research used correlational quantitative methods. Participants in this research was 100 breast cancer patients, which was taken by purposive sampling technique. Data were collected using the Hopelessness Scale from Farran, Herth \& Popovich (in Canisti, 2012) and life satisfaction measured by Life Satisfaction Scale. The correlation was analyzed using the Pearson Correlation Test with SPSS 18 for Windows. The results showed there was a negative and significant relationship between life satisfaction and hopelessness $(r=-0,260 ; p=0,000)$ which means the higher life satisfaction, the hopelessness.
\end{abstract}

Keywords: life satisfaction; hopelessness; breast cancer

\begin{abstract}
Abstrak. Penelitian ini bertujuan untuk menguji hubungan antara kepuasan hidup dengan hopelessness. Hipotesis penelitian ini adalah ada hubungan negatif antara kepuasan hidup dengan hopelessness pada pasien kanker payudara. Penelitian ini menggunakan metode kuantitatif korelasional. Partisipan dalam penelitian ini adalah 64 mahasiswa yang didapatkan dengan teknik purposive sampling. Data dikumpulkan dengan menggunakan Skala Hopelessness dari Farran, Herth \& Popovich (Canisti, 2012) dan Kepuasan Hidup diukur dengan Skala Kepuasan Hidup. Analisis data yang digunakan adalah menggunakan korelasi Product Moment (Pearson Correlation) dengan bantuan SPSS 18 for Windows. Hasil menunjukkan ada hubungan negatif antara kepuasan hidup dengan hopelessness $(\mathrm{r}=-0,260 ; \mathrm{p}=0,000)$, Hal tersebut menunjukkan semakin tinggi kepuasan hidup maka semakin rendah hopelessness.
\end{abstract}

Kata kunci : kepuasan hidup; hopelessness, kanker payudara 


\section{PENDAHULUAN}

\section{Perkembangan zaman yang terjadi di masyarakat bisa menyebabkan terjadinya peralihan pola kehidupan masyarakat tersebut beralih dari pola hidup tradisional ke pola hidup modern. Pola hidup modern yang serba praktis, cepat dan mudah yang bisa memicu pola hidup yang tidak sehat. Pola hidup modern menyebabkan munculnya kebiasaan pola makan serba cepat dan praktis mengakibatkan tuntutan pada}

masyarakat untuk mengabaikan pola hidup sehat. Peralihan pola hidup modern ini, menyebabkan masyarakat mendapatkan makanan dengan sangat mudah seperti pemesanan makanan menggunakan via online. Restoran-restoran dan tempat makan siap saji lainnya mudah didapatkan, tetapi konsumen tidak mempertimbangkan lagi kandungan nutrisi di dalamnya. Pola hidup yang salah dan keliru ini bila menjadi kebiasan akan dapat menimbulkan berbagai penyakit berbahaya salah satunya adalah kanker.

Kanker dalam pengertian sederhana adalah sel yang tumbuh terus-menerus secara tidak terkendali, tidak terbatas, dan tidak normal (abnormal). Pertumbuhan selsel kanker tidak koordinasi dengan jaringan lain sehingga berbahaya bagi tubuh. Konteks lain menyebutkan kanker merupakan tumor ganas yang mengalami pertumbuhan abnormal yang tidak diketahui secara pasti penyebabnya. Dalam kondisi normal, sel hanya akan berkembang biak dengan cara membelah diri jika ada yang mati atau rusak. Sel kanker akan terus mengalami pengembangbiakan meskipun tidak dibutuhkan oleh tubuh. Sel kanker merusak jaringan sel lain yang normal dan menyebar ke organ tubuh melalui jaringan ikat, darah, saraf, dan jaringan penunjang organ tubuh. Bagian organ tubuh yang terserang sel kanker akan terhambat pertumbuhannya. Kanker termasuk penyakit yang tidak menular. Penyakit timbul akibat kondisi fisik yang tidak normal dan pola hidup yang tidak sehat (Mardiana, 2004).

Terdapat berbagai jenis kanker, salah satu jenis kanker adalah kanker payudara. Kanker payudara adalah tumor yang menyerang jaringan payudara. Jaringan payudara tersebut terdiri dari kelenjar susu (kelenjar pembuat air susu), saluran kelenjar (saluran air susu), dan jaringan penunjang payudara. Kanker payudara tidak menyerang kulit payudara yang berfungsi sebagai pembungkus. Kanker payudara menyebabkan sel dan jaringan payudara berubah bentuk menjadi abnormal dan bertambah banyak secara tidak terkendali (Mardiana, 2004).

Kanker payudara merupakan penyakit yang paling ditakuti oleh kaum wanita. Meskipun demikian, berdasarkan penemuan terakhir, kaum pria pun bisa terkena kanker payudara. Dari hasil penelitian menunjukkan bahwa satu dari delapan wanita terkena kanker payudara. Di Indonesia, kanker payudara, merupakan kanker kedua paling banyak diderita kaum wanita setelah kanker mulut atau leher 
rahim. Kanker payudara umumnya menyerang wanita yang telah berumur lebih dari 40 tahun. Namun demikian wanita muda pun bisa terserang kanker ini (Mardiana, 2004).

Kanker payudara merupakan kanker yang paling banyak menyerang perempuan. Diperkirakan jumlah kasus tidak kurang dari 1.050.346 per tahun. Dari jumlah itu, 580.000 kasus terjadi di negara maju, sisanya di negara berkembang. Berdasarkan estimasi International Agency for Research on Cancer, pada tahun 2020 akan ada 1,15 juta kasus kanker payudara dengan 411.000 kematian. Sebanyak 70\% kasus baru dan $55 \%$ kematian diprediksi terjadi di negara berkembang. Data Organisasi Kesehatan Dunia (WHO) tahun 2003 menunjukkan pada tahun 2002 terdapat 24,6 juta penderita semua jenis kanker, 10,9 juta kasus baru, dan 6,7 juta kematian akibat kanker. Menurut International Union Against Cancer (UICC), sebuah lembaga nonpemerintah internasional yang bergerak di bidang pencegahan kanker. Kanker telah telah membunuh orang lebih banyak daripada total kematian yang diakibatkan AIDS, Tuberkolusis, dan Malaria. Jumlah kematian akan meningkat secara dramatis dalam dekade mendatang. Pada tahun 2030 diperkirakan lebih dari 12 juta orang akan mati akibat kanker per tahun (Rasjidi, 2010).

Kanker payudara adalah keganasan yang berasal dari sel kelenjar, saluran kelenjar, dan jaringan penunjang payudara tidak termasuk kulit payudara. kanker payudara (KPD) merupakan keganasan pada jaringan payudara yang dapat berasal dari epitel duklus maupun lobukusnya. Kanker payudara merupakan salah satu jenis kanker terbanyak di Indonesia. Berdasarkan Pathological Based Registration di Indonesia, kanker payudara menempati urutan pertama dengan frekuensi relatif sebesar 18,6\% (Data kanker di Indonesia Tahun 2010, menurut data Histopatologi; Badan Registrasi Kanker Perhimpunan Dokter Spesialis Patologi Indonesia (IAPI) dan Yayasan Kanker Indonesia (YKI) diperkirakan angka kejadiannya di Indonesia adalah 12/100.000 wanita, sedangkan di Amerika adalah sekitar 92/100.00 wanita dengan mortalitas yang cukup tinggi yaitu 27/100.000 atau 18\% dari kematian yang dijumpai pada wanita. Penyakit ini juga dapat diderita pada laki-laki dengan frekuensi sekitar $1 \%$. Di Indonesia, lebih dari $80 \%$ kasus ditemukan berada pada stadium yang lanjut, dimana upaya pengobatan sulit dilakukan (Kementrian Kesehatan, 2009).

Berdasarkan survei awal yang dilakukan di RSUD Arifin Achmad Provinsi Riau terdapat sejumlah data pasien penderita kanker payudara pada periode Januari-Mei 2017 yaitu sebanyak 100 orang pasien rawat jalan. Beberapa pasien sulit melakukan aktivitas sehari-hari, mengalami susah tidur, berfikir mengapa mereka mendapatkan penyakit ini pada diri pasien, hingga pasrah terhadap apa yang sedang pasien alami saat ini. Berdasarkan penjelasan $\mathrm{di}$ atas dapat dilihat bahwa dilihat bahwa penderita kanker payudara membuat 
penderitanya mengalami hopelessness.

Menurut Carpenito (2000), hopelessness adalah suatu kondisi emosional seseorang di mana individu tersebut melihat tidak ada lagi alternatif atau pilihan pribadi yang tersedia untuk mengatasi masalah atau untuk mencapai apa yang diinginkan dan tidak dapat menggerakkan energi diri sendiri untuk membuat tujuan. Hopelessness merupakan suatu kondisi subjektif seseorang individu melihat tidak ada alternatif atau pilihan pribadi yang tersedia dan tidak dapat memobilisasi energi yang dimilikinya (Wilkinson, 2007).

Menurut Farran, Herth, dan Popovich (Canisti, 2012), hopelessness dalam tiga komponen yaitu komponen afektif, yaitu cara merasakan sesuatu, komponen kognitif atau cara berpikir, komponen behavioral atau cara bertindak.

Hopelessness dipengaruhi oleh beberapa faktor yaitu, memburuknya kondisi fisik atau stres jangka panjang, Kehilangan kepercayaan pada kekuatan spiritual dan isolasi sosial (Sparks \& Taylor, 2014). Berdasarkan penelitian terdahulu menunjukkan bahwa kepuasan hidup mempengaruhi hopelessness yang dilakukan oleh Çakar, Tagay dan Karatas (2012) terdapat korelasi negatif yang signifikan antara kepuasan hidup terhadap hopelessness pada remaja di Burdur. Penelitian ini membuktikan bahwa peningkatan perasaan hopelessness tentang masa depan dikaitkan dengan penurunan kepuasan hidup.

Satisfaction merupakan satu keadaan kesenangan dan kesejahteraan, disebabkan karena orang telah mencapai satu tujuan atau sasaran (Chaplin, 2006). Kepuasan hidup adalah kesejahteraan psikologis secara umum atau kepuasan terhadap kehidupan secara keseluruhan kepuasan mengarah pada kesejahteraan psikologis secara umum, pendapatan, kesehatan, gaya hidup yang aktif serta jaringan keluarga dan pertemanan dikaitkan dengan jalan yang memungkinkan tercapainya kepuasan hidup (Santrock, 2002). Hurlock (2004) menyatakan aspek-aspek dari kepuasan hidup adalah menerima (acceptance), kasih sayang atau cinta (affection), prestasi (achievement).

Berdasarkan latar belakang yang telah diuraikan di atas maka penelitian ini bertujuan untuk mengetahui Hubungan Antara Kepuasan Hidup Dan Hopelessness pada Pasien Kanker Payudara.

\section{METODE}

Penelitian ini termasuk jenis penelitian kuantitatif dengan metode penelitian korelasi product moment. Pengambilan data dilakukan di RSUD Arifin Achmad Provinsi Riau. Subjek penelitian ini adalah pasien kanker payudara berjumlah 100 orang. Teknik sampling yang digunakan dalam penelitian ini adalah total sampling. Karakteristik yang digunakan dalam penelitian ini adalah pasien kanker payudara rawat jalan, berjenis kelamin perempuan, usia 25-65 tahun, dan bias berbahasa Indonesia.

Alat ukur yang digunakan untuk mengukur hopelessness dalam penelitian ini adalah skala hopelessness terdiri dari 48 aitem 
disusun berdasarkan aspek yang dikemukakan oleh Farran, Herth, dan Popovich (Canisti, 2012) yang terdiri dari affective component, yaitu cara merasakan sesuatu, cognitive component atau cara berpikir, behavioral component atau cara bertindak. Pada skala hopelessness ini diperoleh koefisien reliabilitas alpha sebesar 0.887 .

Instrumen yang digunakan untuk mengukur kepuasan hidup dalam penelitian ini dengan skala kepuasan hidup yang terdiri dari 48 aitem, berdasarkan aspek dari Hurlock (2004) menerima (acceptance), kasih sayang atau cinta (affection), prestasi (achievement), dengan koefisien reliabilitas Cronbach's Alpha sebesar 0,951. Menurut Azwar (2012), salah satu ciri instrumen ukur yang berkualitas baik adalah reliable, yaitu mampu menghasilkan skor yang cermat dengan error pengukuran kecil. Reliabilitas mengacu kepada keterpercayaan atau konsistensi hasil ukur, yang mengandung makna seberapa tinggi kecermatan pengukuran. Koefisien reliabilitas berada dalam rentang angka dari 0 sampai 1,00. Maka dapat dikatakan bahwa skala kepuasan dan kala hopelessness ini memiliki reliabilitas yang baik.

Penelitian ini menggunakan metode skala terpakai (try-out terpakai) sehingga hanya satu kali penyebaran skala.

\section{HASIL DAN PEMBAHASAN}

\section{Hasil}

Hasil analisis deskriptif diperoleh skor hopelessness minimum 40 dan 80 maksimum (M
$=62,80$ dan $\mathrm{SD}=10,350$ ), dengan hasil kategorisasi bahwa subjek yang memiliki hopelessness rendah ada sebanyak 19 orang atau 19 persen dan subjek yang memiliki hopelessness sedang ada sebanyak 79 orang atau 79 persen. Sementara subjek yang memiliki hopelessness tinggi sebanyak 2 orang atau 2 persen. Sedangkan skor kepuasan hidup diperoleh 42 minimum dan 98 maksimum $(\mathrm{M}=64,31$ dan $\mathrm{SD}=$ 14,093). Dari hasil kategorisasi bahwa terdapat 34 subjek atau 34 persen dengan kepuasan hidup yang rendah, sedangkan subjek yang memiliki kepuasan hidup sedang adalah sebanyak 62 orang atau 62 persen, dan subjek yang memiliki kepuasan hidup tinggi adalah sebanyak 4 orang atau 4 persen.

Berdasarkan uji korelasi yang dilakukan digunakan uji Product Moment (Pearson Correlation) diperoleh nilai sebesar 0,260 dengan p sebesar 0,005 ( $<$ < 0,05; Sig. 1tailed). Hasil tersebut dapat disimpulkan bahwa hipotesis yang terdapat diajukan dalam penelitian ini menunjukkan ada hubungan negatif antara kepuasan hidup dan hopelessness pada pasien kanker payudara dinyatakan dapat diterima. Hal tersebut dapat disimpulkan bahwa semakin tinggi kepuasan hidup individu, maka semakin rendah hopelessness dan sebaliknya semakin rendah kepuasan hidup, maka semakin tinggi hopelessness.

\section{Pembahasan}

Dari hasil penelitian ini dapat diketahui bahwa ada kesesuaian dengan teori yang dikemukakan oleh (Schmale \& Iher dalam Carpenito, 2000) bahwa para individu yang 
diperkirakan menderita kanker dalam data dasar pengkajiannya ditemukan adanya hopelessness yang menyelimuti seluruh kehidupannya seperti klien yang sudah didiagnosa kanker, suatu penyakit-penyakit terminal yang dapat menyebabkan rasa putus.

Hopelessness memiliki

pengaruh terhadap kepuasan hidup ini dibuktikan dengan adanya penelitian terdahulu dilakukan oleh Capri, dkk., (2014) terhadap 461 siswa di Turki, yang menemukan bahwa ada hubungan negatif signifikan antara kepuasan hidup dan hopelessness.

Penelitian ini diperoleh koefisien determinasi sebesar 0,068 yang berarti variabel kepuasan hidup memberikan sumbangan sebesar 6,8 persen. Hal ini menunjukkan bahwa 93,2 persen tingkat hopelessness dipengaruhi oleh faktor lain. Dapat disimpulkan bahwa kepuasan hidup dapat meningkatkan rasa bersyukur, semangat dan berusaha untuk bisa sembuh. Dengan begitu mereka menjadi lebih sehat dan bahagia. Dengan adanya kepuasan dalam hidup akan mengurangi rasa hopelessness pada diri pasien.

Penjelasan

di atas menunjukkan bahwa adanya hubungan yang signifikan negatif antara kepuasan hidup dan hopelessness. Semakin tinggi kepuasan seorang individu maka semakin rendah hopelessness yang akan dialami individu tersebut, dan sebaliknya semakin rendah kepuasan hidup yang ada di dalam diri individu tersebut maka semakin tinggi hopelessness.

\section{SIMPULAN}

Berdasarkan hasil penelitian yang telah dilakukan, hasil uji korelasi menunjukkan adanya hubungan negatif dan signifikan antara kepuasan hidup dengan hopelessness pada pasien kanker payudara. Penelitian ini menunjukkan rata-rata pasien kanker payudara yang menjalani perawatan memiliki tingkat hopelessness yang sedang. Pasien kanker payudara yang menerima, mendapatkan cinta dan kasih sayang dari keluarga, keluarga, tetangga, teman, dan mencapai sebuah tujuan cenderung memiliki hopelessness rendah.

\section{DAFTAR PUSTAKA}

Azwar, S. (2012). Penyusunan Skala Psikologis. Yogyakarta: Pustaka Pelajar

Canisti, R. (2012). Penyusunan Skala Keputusasaan Untuk Pasien Penyakit Kronis (Studi Pada Pasien Gagal Ginjal Kronis yang Menjalani Terapi Hemodialisis). Jurnal Psikogenesis, 13(5). Diakses pada tanggal 4 Maret 2017 dari academicjournal.yarsi.ac.id/in dex.php/Jurnal-OnlinePsikogenesis/article/.../5/pdf

Chaplin, J. (2006). Kamus Lengkap Psikologi. Jakarta: PT. RajaGrafindo Persada

Carpenito, L. J. (2000). Diagnosa Keperawatan: Aplikasi Pada Praktik Klinis. Jakarta: 
Penerbit Buku Kedokteran EGC

Çakar, Tagay \& Karataş. (2012). The Self-Esteem, Perceived Social Support and Hopelessness in Adolescents: The Structural Equation

Modeling.Educational

Sciences: Theory \& Practice, 12(4). Diakses pada tanggal 5 Maret 2017 dari http://www.kuyeb.com/pdf/en/ 5a10f493b6bd15cec2ec38ff0f8 6401karen.pdf

Capri, Gündüz \& Akbay.(2013). The Study of Relations between Life Satisfaction, Burnout, Work Engagement and Hopelessness of High School Students. International Education Studies, 6(11); 2013. ISSN 1913-9020. E-ISSN 1913-9039. Diakses pada tanggal 8 Juni 2017

darihttps://files.eric.ed.gov/full text/EJ1068744.pdf

Hurlock, E. B. (2004). Psikologi Perkembangan. Jakarta: Erlangga

Kementrian Kesehatan. (2009). Panduan penatalaksanaan kanker payudara. Jakarta: Kementrian Kesehatan Republik Indonesia

Mardiana, L. (2004). Kanker Pada Wanita. Jakarta: Seri Agrisehat. Diakses pada tanggal 4 Maret 2017 dari https://books.google.co.id/book s? id=IYCN1e9JtQcC\&pg=PR4 $\& l p g=P R 4 \& d q=$ mardiana +200
$4 \&$ source $=$ bl\&ots $=6 y g I c 3 f S p q$ \&sig=jFw4TIZXANm0gpDQ 4hHhwqNunE\&hl=id\&sa $=X \& r$ edir_esc $=\mathrm{y} \# \mathrm{v}=$ onepage $\& \mathrm{q}=$ mar diana $\% 202004 \& \mathrm{f}=$ false

Rasjidi, I. (2010). Epidemiologi Kanker Pada Kanker. Jakarta: Sagung Seto

Santrock, J.W. (2002). Life Span Development Perkembangan Masa Hidup. Edisi:5. Jakarta: Erlangga

Sparks \& Taylor. (2014). Nursing Diagnosis Pocket Guide. China: Wolters Kluwer Health / Lippincott Wiliams \& Wilkins. Diakses pada tanggal 4 Maret 2017 dari https://books.google.co.id/book $\mathrm{s}$ ? id=fbBKVK3QwREC\&pg=P A185\&dq=hopelessness+spark $\mathrm{s}+$ and+taylor \&hl $=\mathrm{id} \& \mathrm{sa}=\mathrm{X} \& \mathrm{v}$ ed=0ahUKEwjkm6zZ2MTVA hVBrY8KHazKAnoQ6AEIJT

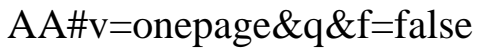

Wilkinson, J. M. (2007). Buku Saku Diagnosa Keperawtan Dengan Intervensi NIC Dan Kriteria Hasil NOC (Edisi: 7). Alih bahasa widyawati. Jakarta 